\title{
Genetics in Dentistry - A Review Article
}

\section{Rohit Kulshrestha, Shailesh Shenava, Prakash Mudaliar, Robin Mathew, Sandeep Singh, Prachi Gaonkar \\ Department of Orthodontics and Dentofacial Orthopedics, Terna Dental College and Hospital, Navi Mumbai, Maharashtra India}

Correspondence to: Rohit Kulshrestha, Department of Orthodontics and Dentofacial Orthopedics, Terna Dental College and Hospital, Navi Mumbai, Maharashtra, India; E-mail: kulrohit@gmail.com

Received date: April 7, 2020; Accepted date: April 16, 2020; Published date: April 24, 2020

Citation: Kulshrestha R, Shenava S, Mudaliar P, et al. (2020) Genetics in Dentistry - A Review Article. Advanc Dentistry. 1(1): pp. 1-3.

Copyright: (C2020 Kulshrestha R. This is an open-access article distributed under the terms of the Creative Commons Attribution License, which permits unrestricted use, distribution, and reproduction in any medium, provided the original author and source are credited.

\section{ABSTRACT}

Most genetic disorders present in early childhood, some even in utero. The diagnosis and management of genetic disorders is, therefore, an important part of fetal medicine and pediatrics, including pediatric dentistry. Clinical genetics, which traditionally is responsible for genetic counseling, is an important collaborator. This article summarises the recent findings in genetics and elaborates on its benefits as well.

\section{Keywords:}

Genetics, Counselling, Genes

\section{Introduction}

Genetics is a branch which deals with the science of potentials. It deals with the study of biological information and transfer from cell to cell, from parents to their offspring, and thus from generation to generation. Genetics has revealed that individuals share $99.9 \%$ of their DNA sequences and their characteristics. Thus, the remarkable diversity of humans is seen in about $0.1 \%$ of our DNA [1]. Genetics is the science of heredity and its variation. It plays an important role in the determination of individuality characteristics [2]. The term "genetics" conveys with the two different concepts: genetics deals with the study of inherited characteristics, and genetics deals with the study of cellular processes controlled by DNA. Developmental defects of teeth can occur as the isolated genetic traits, can be associated with a chromosomal abnormality or syndrome, or can be inherited as a complex trait with the genetic and environmental interactions [3]. Numerous hereditary syndromes have been associated with congenitally missing teeth. Often pediatric dentists are the first health care practitioners to document dysmorphic characteristics features in a child. They need to know about molecular genetics because the sensitivity and specificity of molecular-based diagnostics have revolutionized the diseases and disorders [4].

\section{Historical perspective}

Stent (1971) showed the first evidence of inheritance was taught and developed by the Hippocrates in the fifth century $\mathrm{BC}$ in Greece. Hippocrates's ideas can be termed as bricks and mortar theory' which states that the hereditary material consists of physical matter. His postulates state that the elements from all parts of the body became concentrated in the male semen and then formed into a human in the womb. He also believed in the inheritance of acquired characteristics [5].

\section{The advent of protein and DNA}

Sequencing had launched a new era of phyllo genetics. Species could now be compared at the biological molecular level. The information age is essential to the genomics. The electronic analysis, distribution, and storage of the genomic data is a hallmark of the science [6].

\section{Fundamentals of genetics}

The genome contains the entire genetic component of a set of chromosomes present within the cell or an organism. Within the genome are the genes that represent the smallest physical and functional units of inheritance that reside in specific sites called loci or locus for a single location site [7]. The term gene was first coined by Wilhelm Johannsen in 1909. The gene was first defined as the unit of genetic information that controls a specific aspect of the phenol type. At a more fundamental level, the gene has been defined as the unit of genetic information that specifies the synthesis of single polypeptide [8].

\section{Functions of genes}

Genes accomplish their function

1. Through the replication that results in more units like themselves.

2. Through transcription and translation processes, whereby proteins that function as determiners in the metabolism of a cell are synthesized.

3. Genes act by determining the structure of proteins, which are responsible for directing the cell metabolism process through their activity as enzymes [9].

\section{Genetics and dental caries}

Genetics in dental caries through twin studies, dental caries is a disease of the dental hard tissues, characterized initially by the decalcification of tooth. Studies of the etiology of dental caries suggested that both genetic and environmental factors may be concerned with the development of the dental caries process. Several major genes have been identified which the condition of defective formation of enamel or dentine leading to the development of rampant caries in such teeth [6].

\section{Genes and saliva}

Human saliva is a compound mixture of proteins. Kauffman and Keller estimated that as much as two-thirds of parotid salivary proteins belong to a caries process and contributes to the greater monozygotic similarity in dental caries experience are:

- Salivary factors and oral flora

- Tooth eruption time and sequence

- Tooth morphology

- Arch shape

- Dental spacing [7] 


\section{Genetic modification of dental enamel altering susceptibility}

Amelogenin, is the protein product of the AMELXXp22.3-p22.1 and AMELY Yp11 genes, is considered to be critical for normal enamel thickness and structure of tooth [8]. Amelogenin is likely to be the candidate gene for caries susceptibility in humans and has differential expressions in males versus females [9]. Mutations and deletions in amelogenin cause one of the forms of X-linked Amelogenesis imperfecta. Ameloblastin is expressed as, during the differentiation of inner enamel epithelium into ameloblasts, with intense localization in the Tomes processes of secretor ameloblastic cells [10].

\section{Genetics and chromosomal disorders}

1. Chromosomal disorders are caused by an abnormality in chromosome number or their structure.

2. Mendelian disorders are caused by the abnormality of a single gene.

3. Non-Mendelian disorders are caused by mitochondrial mutations or altered gene expressions resulting from the imprinting. Chromosomal disorders are congenital or acquired [11].

Acquired chromosomal disorders are important in the pathogenesis and evolution of hematologic, solid organ malignancies [12]. Congenital chromosomal disorders occur in the ratio of approximately 1 in 150 live births; they except for $X$ and $Y$ chromosomal disorders occur in pediatric age groups. Trisomy 21 Syndrome Down's syndrome, or mongolism, is one of the most common identifiable malformation syndrome. In 1866, Langdon Down published an essay in England in which he described, that a set of children having common features who were distinct from other children with mental retardation that he named Mongolian idiocy $[13,14]$.

\section{Cherubism}

Hereditary fibrous dysplasia of the jaws, familial intraosseous swellings of the jaws, Familial multilocular cystic disease of the jaws). Cherubism is a hereditary condition that produces firm, painless swellings that occur bilaterally in the jaws, especially over the mandibular angles or regions [16]. The impact of cherubism lesions was on the development and eruption of the primary and permanent dentition varies depending on the time of onset and severity of the extending lesions. The alignment of primary teeth can be disturbed. Disruption of the secondary dentition can include absent teeth (mostly molars), anodontia [17].

Amelogenesis Imperfecta (AI) is a group of inherited defects of enamel formation that show both the clinical and genetic heterogeneity characters. In its mildest form, Al causes discoloration, while in the most severe presentation the enamel is in hypo mineralized condition leading to be abraded from the teeth shortly after their eruption into the mouth. Both the primary and permanent dentitions are affected [18].

\section{Class III Malocclusion}

Class III malocclusion features affect multiple craniofacial structures, from large mandible to small maxilla to cleft lip and palate. These features appear early in development, worsen with age, and are present in most Class III individuals regardless of ethnicity. A recent study in 292 Caucasian adults identified six principal components which accounted for
$81 \%$ of the phenotypic variation recorded. About $54 \%$ of the variation was explained by the Anterior-Posterior (AP) position of the mandible compared to the cranial base, the size of the maxillomandibular horizontal discrepancy, and the lower incisor AP position. Cluster analyses identified five distinct phenotypic subgroups which were remarkably similar to those found by previous studies.

\section{Genetics and periodontal diseases}

Periodontal diseases are a heterogeneous group of diseases characterized by different degrees of pathological changes in the periodontium. It destroys the supporting structures and most of the destructive processes involved are host-derived factors.

\section{Early-onset periodontitis (Aggressive periodontitis)}

Aggressive periodontitis was previously classified as early onset periodontitis. It was included as pre-pubertal, juvenile and rapidly progressive forms of periodontitis. Aggressive periodontitis classified as localized or generalized [19]. In localized aggressive periodontitis, there is interproximal attachment loss on at least two permanent teeth (first molars and incisors) with attachment loss on no more than two teeth other than first molars and incisors. Generalized aggressive periodontitis patients exhibit generalized interproximal attachment loss features including at least three teeth that are not first molars and incisors [20].

\section{Gingival Enlargement}

It is the overgrowth of gingiva identified by an expansion and accumulation of the connective tissue fluid with the occasional presence of an increased number of cells in it. Gingival enlargement may result from the chronic gingival inflammation. It may occur as drug-related side effects complications in some individuals [21].

\section{Genetic Testing}

Genetic screening denotes assays undertaken on a populationwide basis to recognize the at-risk individuals. Genetic testing\|, designed to provide a definitive diagnosis treatment; these are performed because of positive screening results, family history, ethnicity, physical stigmata, or other multifactorial reasons [22].

Diagnostic testing: Diagnostic testing is done to diagnose or rule out specific genetic or chromosomal conditions.

Carrier testing: Carrier testing is used to recognize people who carry one copy of Gene mutation characters that, when present in two copies, causes a genetic disorder [23].

Prenatal diagnosis: Used to diagnose changes in fetus genes or chromosomes before birth [24].

\section{Genetic Counselling}

Modern genetic counseling is a communication process between a healthcare professional trained in genetics and an individual and family affected by inherited diseases. The goals of this process included spreading the knowledge of medical and dental facts, to understand the contribution of hereditary conditions and its risk factors [25].

\section{Conclusion}

Genetic disorders are now-a-days seen to be attended with less importance than other diseases in public health problems. In 
underdeveloped countries, neonatal and natal infant mortality is mostly due to a lack of knowledge and ignorance in prevention among the public. Therefore, for better understanding of genetic causes of diseases can facilitate early detection in highrisk individuals

\section{References}

1. Sturtevant $A H$ (1965) A history of genetics.

2. McClean P (2011)A History of Genetics and Genomics..

3. Snustad DP, Simmons MJ (2002) Principles of genetics 5th edition, Asia.

4. Cooper GM, Hausman RE (2009) The cell- A molecular approach 5th edition. ASM press.

5. Gardner EJ, Snustad DP (1984) Principles of genetics 7th edition. Singapore.

6. Vieira AR (2012) Genetics and Caries-Perspectives. Braz Oral Res. 26(Suppl 1): pp. 7-9.

7. Goldberg S (1930) The dental arches of identical twins. Dental Cosmos.72(1): pp. 869-881

8. Bordoni N, Dono R, Manfredi C, et al. (1973) Prevalence of dental caries in twins. J Dent Children. 40(2): pp. 440-443.

9. Mansbridge JN (1959) Heredity and dental caries. J Dent Res. 38(1): pp. 337-347.

10. Finn SB, Caldwell RC (1963) Dental caries in twins I. A comparison of caries experience of monozygotic twins, dizygotic twins and unrelated children. Arch Oral Biol. 8(1): pp.571-585.

11. Boraas JC, Messer LB, Till MJ (1988) A genetic contribution to dental caries, occlusion and morphology as demonstrated by twins reared apart. J Dent Res. 67(9): pp. 1150-1155.

12. Klein H, Palmer CE (1938) Studies of dental caries: V. Familial resemblance in caries experience in siblings. Public Health Rep. 53(2): pp. 1353-1364.

13. Klein H (1946) The family and dental disease: IV. Dental disease experience in parents and off springs. J Am Dent Assoc. 33(11): pp. 735-743.
14. Li Y, Caufield PW (1995) The fidelity of initial acquisition of mutans streptococci by infants from their mothers. J Dent Res. 74(2): pp. 681-685.

15. Goodman HO, Luke JE, Rosen S, et al. (1959) Heritability in dental caries, certain oral microflora and salivary components. Am J Hum Genet. 11(3): pp. 263-73.

16. Mcdonald RE, Avery DR (2004) Dentistry for the Child and Adolescent 8th edition.

17. Fairpo CG (1979) Total caries experience in monozygotic and like-sexed dizygotic twins of Caucasoid origin aged 5 to 15 years. Arch Oral Biol. 24(1): pp. 491-494.

18. Gorlin RJ, Cohen MM, Levin LS (1990) Syndromes of the Head and Neck 3rd Edition. NY: Oxford Univ. Press. pp. 700-704.

19. Korenberg JR (1994) Down syndrome phenotypes: The consequences of chromosomal imbalance. Proc Natl Acad Sci.91: pp. 4997-5001.

20. Patterson D (1995) The integrated map of human chromosome 21. In Etiology and Pathogenesis of Down Syndrome. Wiley-Liss. 43-55.

21. Kalantar MH (1998) Treatment of cherubism with locally aggressive behavior presenting in adulthood: report of four cases and a proposed new grading system. J Oral Maxl Surg. 56(11): pp. 1336-1342.

22. Raposo CE (2007) Two-stage surgical treatment of severe cherubism. Ann Plast Surg. 58(6): pp. 645-651.

23. Thompson $N$ (1959) Cherubism: familial fibrous dysplasia of the jaws. Bri J Plas Surg. 12(1): pp. 89-103.

24. Crawford PJ, Aldred MJ (1992) X-linked amelogenesis imperfecta. Presentation of two kindreds and a review of the literature. Oral Surg Oral Med Oral Pathol. 73(4): pp. 449-455.

25. Li W, Gao C, Yan Y, et al. (2003) X-linked amelogenesis imperfecta may result from decreased formation of Tyrosine Rich Amelogenin Peptide (TRAP). Arch Oral Biol. 48(3): pp. 177183. 